\title{
Production, Optimization, Purification, Testing Anti-Microbial and Dye Decolorizing Properties of Penicillin G Acylase from Penicillium chrysogenum.
}

\author{
Balaji Mahendiran ${ }^{1}$, VigneshwaranDuraisamy ${ }_{* *}^{2}$, \\ AnannyaMohapatra ,MalarselviSethupathy ${ }^{* *}$. \\ 1, 2-DNA Labs India, Hyderabad\&Department of Biotechnology, Government College of Technology, \\ Coimbatore. \\ *- Research Associate, DNA Labs India, Hyderabad. \\ **-Assistant Professor, Department of Biotechnology, Government College of Technology, Coimbatore.
}

\begin{abstract}
The enzyme Penicillin G Acylase (PGA) has been produced from Penicillium chrysogenum obtained from spoiled lemon sample. The physico-chemical parameters like carbon source, $p H$, temperature and media were optimized for higher production of enzyme. The enzyme was purified by ammonium sulphate precipitation followed by Dialysis and Ion-Exchange Chromatography and confirmed by TLC. The purified enzyme was tested for anti-microbial and dye-decolorizing properties. The enzyme showed a clear zone of inhibition when tested against few bacterial pathogens. Then the immobilized enzyme was tested for dye-decolourization activity against Congo red, which showed a very low activity as compared to that of Penicillium chrysogenum.
\end{abstract}

Keywords:Penicillin G Acylase, Optimization, Dye decolourization, Congo red, Anti-pathogenic effect, Ion Exchange Chromatography.

\section{Introduction}

Penicillin G Acylase (EC 3.5.1.11) is an important industrial enzyme used in the production of semisynthetic antibiotics. PGA catalyses the deacylation of penicillin G to produce 6-APA, which is an important intermediate in the manufacture of beta-lactam antibiotics [1]. Many genera of moulds, yeast and bacteria produce penicillin acylases [2]. Penicillium chrysogenum has been reported to have acylase activity and it is the most significant source of several beta lactam antibiotics such as penicillin [3]. Since the enzyme is more commercially used for the production of antibiotics, it is essential to optimize the media for higher yield. In this study the effect of carbon source on the PGA production is studied, followed by the optimization of $\mathrm{pH}$, temperature and other media components. The PGA enzyme was purified by using various methods such as gel filtration, ion exchange chromatography, ultrafiltration, ammonium sulphate precipitation, two-phase extraction systems, etc. [4, 5, $6 \&$ 7]. In this study, the PGA enzyme was purified by ammonium sulphate precipitation, followed by dialysis and ion exchange chromatography. Though the enzyme is used for the cleavage of beta lactam antibiotics, it was also tested for antibiotic activity against four pathogenic microbes. The recovery and reuse of free enzymes are limited and this has resulted in development of wide variety of immobilization techniques. By careful selection of matrix, it is possible to improve enzyme activity and stability, enabling easier handling and storage [8 \& 9]. Several supports were used for PGA immobilization and one of the most used is agarose [10]. In this study, sodium alginate beads were used for immobilization.

Textiles dyes constitute a major source of pollution [11]. Azo dyes are classes of environmental pollutants whose break down products are highly toxic and mutagenic to living organisms [12]. Congo red is a secondary di-azo dye that is widely used in dyeing industries. The concentration of dye contained in the industrial effluent varies between $10-200 \mathrm{mg} / \mathrm{ml}$ depending upon the dying process [9]. Microbial degradation and decolourization of dyes have received much attention from the viewpoint of treating industrial dye effluents [13]. Azo dyes are not readily degraded by microbes, but microorganisms that are able to degrade azo dyes anaerobically have been isolated [14]. The current study compares the dye decolourizing potential of Penicillium chrysogenum with that of the Penicillin G Acylase enzyme against Congo red dye [15].

\subsection{Chemicals}

\section{Materials And Methods}

The potassium salt of Penicillin G, PDAB, $\mathrm{KH}_{2} \mathrm{PO}_{4}, \mathrm{~K}_{2} \mathrm{HPO}_{4}, \mathrm{FeSO}_{4}, \mathrm{MgSO}_{4}$, Sucrose, LPCB stain, yeast extract, peptone, acetic acid, methanol, ethanol, butanol, butyl acetate, sodium bicarbonate, DEAE cellulose, $\mathrm{NaCl}$, Tris- $\mathrm{HCl}$, L-cysteine, Ammonium sulphate were purchased from purchased from Hi-media Laboratories (Mumbai, India). The commercially available Congo red dye was used for this study. 


\subsection{Microorganism}

Spoiled lemon samples were collected from market (Kachiguda, Hyderabad) and were plated onto potato dextrose agar medium. The fungal colonies produced were tested for penicillin acylase production using acidimetric method. The acylase producing microorganisms were stained using LPCB stain and viewed under microscope. Based on the morphological and colony characteristics it was confirmed as Penicillium chrysogenum.

\subsection{Production}

Nutrient medium $\left(\mathrm{MgSO}_{4^{-}} 0.02 \%, \mathrm{KH}_{2} \mathrm{PO}_{4^{-}} 0.3 \%, \mathrm{~K}_{2} \mathrm{HPO}_{4^{-}} 0.9 \%\right.$, Glucose- $2 \%$, Yeast extract- $0.5 \%$, Penicillin- 1\%) was prepared and inoculated with the isolated pure cultures of Penicillium chrysogenum. The medium was incubated at $37^{\circ} \mathrm{C}$ and $\mathrm{pH} 7$ for overnight. The enzyme activity was found using PDAB assay method. One unit of enzyme activity corresponds to the amount of enzyme which cleaves $1 \mu \mathrm{mol}$ of penicillin $\mathrm{G}$ in $10 \mathrm{mM}$ phosphate buffer to 6-APA per minute at $\mathrm{pH} 8$ and $37^{\circ} \mathrm{C}$. The concentration of 6-APA was found from plotting the cysteine standard graph against the spectrophotometer optical density at $415 \mathrm{~nm}$ [16]. The nature of the enzyme was found by testing the enzyme activity on supernatant and pellet of the cell suspension. Enzyme activity was measured using the formula,

\subsection{Optimization}

$$
\text { E. U. }(\mu \mathrm{g} . \min -1)=\frac{\text { Concentration of } 6-\text { APA }(\text { in } \mu \mathrm{g} / \mathrm{mL})}{\text { Mol. wgt. of } 6-\text { APAx Time of reaction }}
$$

\subsubsection{Effect of carbon source}

The effect of carbon source was studied by varying the carbon sources as sucrose, glucose, lactose and fructose, keeping the other components constant at $37^{\circ} \mathrm{C}$ and $\mathrm{pH} 7$ for 3 days.

\subsubsection{Effect of micronutrients}

The effect of essential micronutrients such as $\mathrm{MgSO}_{4}, \mathrm{KH}_{2} \mathrm{PO}_{4}$ and $\mathrm{K}_{2} \mathrm{HPO}_{4}$ on the PGA production was studied by varying them individually in each medium at different concentrations $\left(\mathrm{MgSO}_{4}-0.01 \%, 0.02 \%\right.$, $0.03 \%, 0.04 \% ; \mathrm{KH}_{2} \mathrm{PO}_{4}-0.2 \%, 0.3 \%, 0.4 \%, 0.5 \%$; and $\mathrm{K}_{2} \mathrm{HPO}_{4}-0.6 \%, 0.7 \%, 0.8 \%, 0.9 \%$ ) keeping the other components as constant at $37^{\circ} \mathrm{C}$ and $\mathrm{pH}$ 7. Three individual experiments were done for each concentration and average of three was plotted in graph.

\subsubsection{Effect of physical parameters}

The effect of temperature on the optimized media was tested at different temperature as $20,30,40 \&$ $50{ }^{\circ} \mathrm{C}$ and $\mathrm{pH} 6$ to 9 . The effect was measured after 3 days. The $\mathrm{pH}$ was adjusted using $1 \mathrm{~N} \mathrm{HCl}$ and $1 \mathrm{~N} \mathrm{NaOH}$.

\subsection{Purification}

From the production media the culture was filtered and the filtrate was precipitated using ammonium sulphate precipitation method. In this, the filtrate was mixed with $44 \%$ of ammonium sulphate in pinch by pinch on ice cold condition. Then the mixture was centrifuged and the pellet was mixed with Tris- $\mathrm{HCl}$ buffer and dialysis was performed. The dialysis membrane was pre-treated with $2 \%$ sodium bi-carbonate and boiled for 10 minutes. Then the membrane is filled with ammonium sulphate precipitated solution. The setup was left overnight and the solution was collected from the membrane and is then taken for Ion Exchange Chromatography. The column was prepared using DEAE- cellulose. The column was equilibrated with Tris-HCl and $\mathrm{NaCl}$ buffer. Then 6 elution buffers were prepared by mixing sample with the different concentrations of Tris- $\mathrm{HCl}(25 \mathrm{mM}, 50 \mathrm{mM}, 75 \mathrm{mM}, 100 \mathrm{mM}, 125 \mathrm{mM}, 150 \mathrm{mM})$ and $\mathrm{NaCl}(25 \mathrm{mM})$. These elutes were collected and tested for that elute having maximum enzyme activity. A small amount of the purified enzyme was confirmed by silica gel thin-layer chromatography with butyl acetate: 1-butanol: acetic acid: water (80:15:40:24) mixture as running solvent for $1 \mathrm{hr}$. For the detection of benzyl penicillin and 6-APA, the chromatograms were air dried, and incubated in an iodine chamber for few minutes [17].

\subsection{Anti-microbial activity of PGA}

The enzyme has the ability to hydrolyse the beta lactam rings of the penicillin and produce 6aminopenicillanic acid that leads to the production of different semi-synthetic antibiotics. Hence PGA was tested for anti-pathogenic activity against the four pathogens such as Streptococcus mitis, Streptococcus pyogenes, Pseudomonas aeruginosaand Micrococcus variansgifted by DNA Labs India, Hyderabad, India. The four pathogens were spread on the nutrient agar plate in which two wells were created for crude and purified enzymes. The zone of inhibition was measured after overnight incubation at $37^{\circ} \mathrm{C}$. 


\subsection{Dye-decolourizing activity of PGA}

PGA was tested for dye decolorizing activity against Congo red dye. The purified enzyme and Penicillium chrysogenum was immobilized using $3 \%$ sodium alginate beads. The immobilized cells and enzyme (activity - .0555 $\mu \mathrm{g} / \mathrm{min}$ ) were used for this study. The immobilized enzyme beads were dissolved in phosphate buffer $(0.1 \mathrm{M})$ with $0.01 \mathrm{~g} / \mathrm{l}$ of dye. Immobilized cells were introduced in the nutrient medium of $\mathrm{MgSO}_{4}$ $0.02 \%, \mathrm{KH}_{2} \mathrm{PO}_{4^{-}} 0.3 \%, \mathrm{~K}_{2} \mathrm{HPO}_{4^{-}} 0.9 \%$, Glucose- $2 \%$, Yeast extract- $0.5 \%, \mathrm{FeSO}_{4^{-}} 0.05 \%, \mathrm{KCl}-0.5 \%$, sodium nitrate $-0.1 \%$ with $0.01 \%$ Congo dye. Since the previous studies have shown that the fungal microorganisms will have more activity against dye solution in chemically defined medium than the normal medium. Percentage of dye decolourization was determined by spectrophotometry at $600 \mathrm{~nm}$. Decolourizing activity was calculated using the following formula. $\mathrm{D}=[(\mathbf{A 0}-\mathbf{A 1}) / \mathbf{A 0}] \mathbf{x} \mathbf{1 0 0}$. Where, $\mathrm{D}=\%$ of decolourization; $\mathrm{A} 0=$ initial absorbance; $\mathrm{A} 1=$ final absorbance $[10]$.

\subsection{Identification of Microorganism}

\section{Results \& Discussion}

In the present study, fungal colonies were isolated from rotten lemon sample. Preferably lemon waste was chosen because it was the cheapest and most abundantly available source. The spoiled lemon samples were plated in potato dextrose agar medium and penicillin acylase producers were identified using acidimetric method as in Fig.1. Appearance of deep red colour from violet indicates the presence of PGA. The PGA producers were again plated on pure Czapek-dox agar plates from which colony characteristics were studied as shown in Fig.3. Pure colonies were isolated from the sub-cultured fungal colonies and their colony morphology was in concordant with standard morphological reports of Penicillium chrysogenum [37].Microscopic characters were studied by staining as shown in the Fig.2. For the identification of microscopic characteristics, a special fungal stain called lacto phenol cotton blue was used to stain the microorganism. Finally by comparing the colony and microscopic characteristics, the isolated fungi were identified as Penicillium chrysogenum colonies Table.1.

\subsection{Enzyme activity assay}

The activity of the enzyme was determined by performing the PDAB assay. The concentration of 6APA was determined from cysteine standard. [16]. Activity of the enzyme was calculated from the formula. The nature of the enzyme was identified as extracellular type, since the activity of enzyme was higher in supernatant than in pellet. Penicillin acylase producers were identified by acidimetric method as 6-APA produced deep red colour on reaction with Phenol red, indicating production of Penicillin $G$ acylase [7]. Enzyme activity was found from PDAB assay using cysteine as standard, wherein the bioconversion of penicillin G into 6-APA occurs due to the presence of Penicillin $G$ acylase. From determination of enzyme characteristics, it was observed that PGA was present only in supernatant and higher enzyme activity of $0.4 \mu \mathrm{g} / \mathrm{min}$ was observed on third day of incubation.

\subsection{Optimization}

\subsubsection{Effect of carbon sources}

On varying carbon sources such as glucose, fructose, lactose and sucrose in nutrient medium the PGA production was studied. It was found that the enzyme activity was more in glucose medium than the medium containing other carbon sources as shown in Fig.4. Optimization of carbon sources indicated that the amount of glucose present in the medium was directly proportional to the enzyme production.

\subsubsection{Optimization of Micronutrients}

The micronutrients such as $\mathrm{MgSO}_{4}, \mathrm{KH}_{2} \mathrm{PO}_{4}$ and $\mathrm{K}_{2} \mathrm{HPO}_{4}$ were optimized by taking each at different concentrations keeping other media components constant. After inoculation of pure cultures of Penicillium chrysogenum into the media, the supernatant from each cell suspension was taken and assayed for enzyme activity after each day of incubation. The optimal concentrations of $\mathrm{MgSO}_{4}, \mathrm{KH}_{2} \mathrm{PO}_{4}$ and $\mathrm{K}_{2} \mathrm{HPO}_{4}$ can be deduced from the following Fig. $(5,6,7)$ obtained after performing the PDAB assay for each successive day.

From the above results, it was found that the optimum concentrations of $\mathrm{MgSO}_{4}, \mathrm{~K}_{2} \mathrm{HPO}_{4}$ and $\mathrm{KH}_{2} \mathrm{PO}_{4}$ were found to be $0.03 \%, 0.7 \%$ and $0.2 \%$ respectively for PGA production and these concentrations had a direct effect on higher production of Penicillin G Acylase.

\subsubsection{Optimization of physical parameters}

The production media was incubated at different temperatures and $\mathrm{pH}$, after inoculating them with pure cultures of Penicillium chrysogenum and optimum values of $\mathrm{pH}$ and temperature was found using the following Fig $(8 \& 9)$. Thus, that the optimum temperature and $\mathrm{pH}$ were found to be $30^{\circ} \mathrm{C}$ and $\mathrm{pH}-8$ respectively. These 
results are in analogous with the previous literatures where similar media optimization studies were carried out $[7,9]$.

\subsubsection{Purification of Penicillin G Acylase}

The enzyme purified after Ammonium sulphate precipitation and Dialysis was taken to perform the ion exchange chromatography. Six different elutes from the anion exchange column was collected and tested individually for enzyme activity by PDAB method. The elute D had the highest enzyme activity. This purified enzyme was loaded on TLC plate and it showed two bands of benzyl penicillin and 6-APA with $\mathrm{R}_{\mathrm{f}}$ values as 0.70 and 0.25 respectively as shown in Fig. 10. Comparing these $R_{f}$ values with previous literature [7], the presence of PGA in elute sample was confirmed since benzyl penicillin and 6-APA are the catalysed products of PGA.

\subsubsection{Antimicrobial activity ofPenicillin G Acylase}

Anti-microbial activity of enzyme was studied by gel-diffusion method and it showed a potent antagonistic effect on bacterial pathogens such as Streptococcus mitis, Streptococcus pyogenes, Pseudomonas aeruginosaand Micrococcus varians as shown in Fig.11,12,13\&14 were inhibition zones for crude(C) and purified enzyme(A) were represented.The diameter of inhibition zone produced by PGA was a maximum against Micrococcus varians measuring about $2.1 \mathrm{~cm} \mathrm{\&} 2.0 \mathrm{~cm}$ for purified and crude enzyme extracts respectively.

\subsubsection{Dye-decolourizing property of Penicillin G Acylase}

The dye decolorizing activity of enzyme and microorganism were studied after immobilizing them in sodium alginate beads [15] and results showed that the immobilized microorganism effectively decolourized dye solution by $64 \%$ than the immobilized enzyme which decolourized only upto $15 \%$ by comparing with control dye solution $(0.01 \%)$ as shown in Fig. 15 \& 16. Thus it was found that the immobilized microorganism had more decolourizing activity against Congo red dye [13].

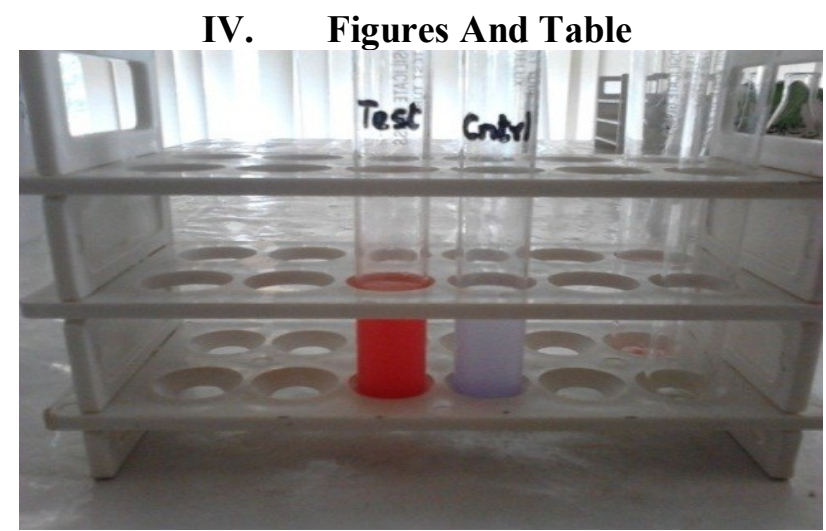

Fig.1 Photograph showing the results of qualitative test for Penicillin acylase activity.

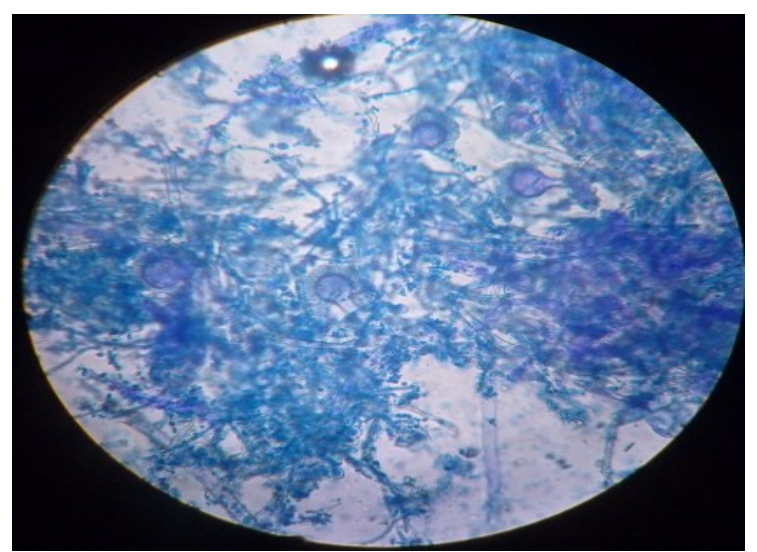

Fig.2 Microscopic image of lacto phenol cotton blue stained Penicillium chrysogenum 


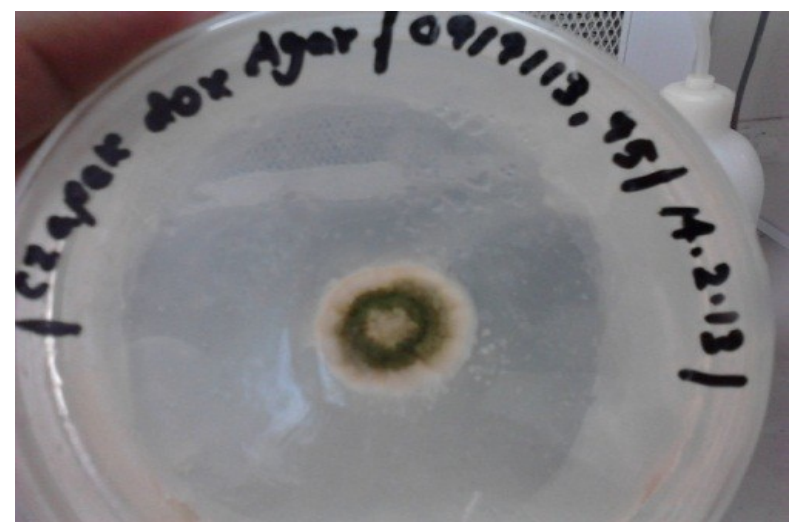

Fig.3 Pure Penicillium chrysogenum colonies were isolated and cultured in czapek-dox agar plates.

Table.1 - Identification of Penicillium chrysogenum from the cultures

\begin{tabular}{|l|l|l|}
\hline \multicolumn{1}{|c|}{ Colony characteristics } & \multicolumn{1}{|c|}{ Microscopic characteristics } & Microorganism identified \\
\hline $\begin{array}{l}\text { Initially white and fluffy, later produced } \\
\text { pigmented spores turn into green or } \\
\text { bluish green. }\end{array}$ & $\begin{array}{l}\text { Hyaline and septate hyphae. } \\
\text { Conidiophores are long. They are branch } \\
\text { and give the brush like appearance. }\end{array}$ & Penicillium chrysogenum \\
Raised, undulate and opaque colonies. & $\begin{array}{l}\text { Sterigmata are long and produce chain of } \\
\text { conidia. Conidia are spherical or oval }\end{array}$ & \\
\hline
\end{tabular}

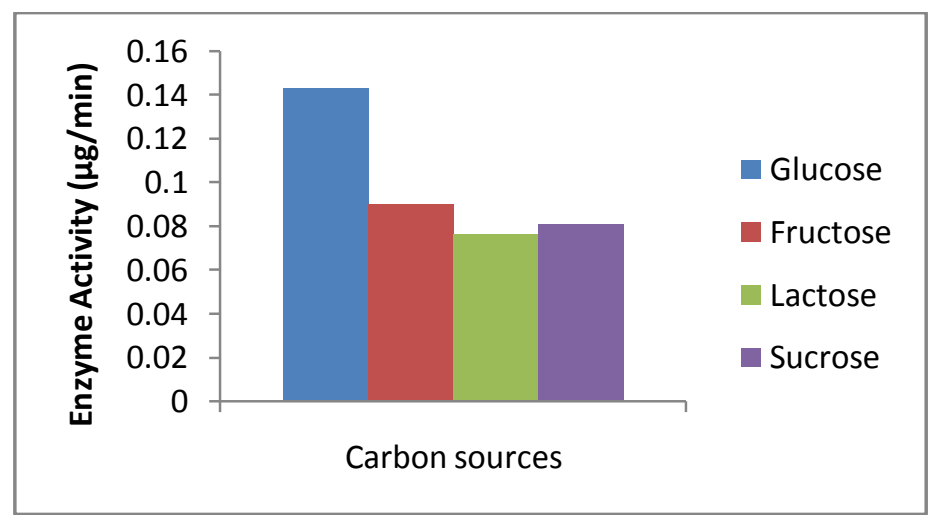

Fig.4. Enzyme units of PGA at different carbon sources.

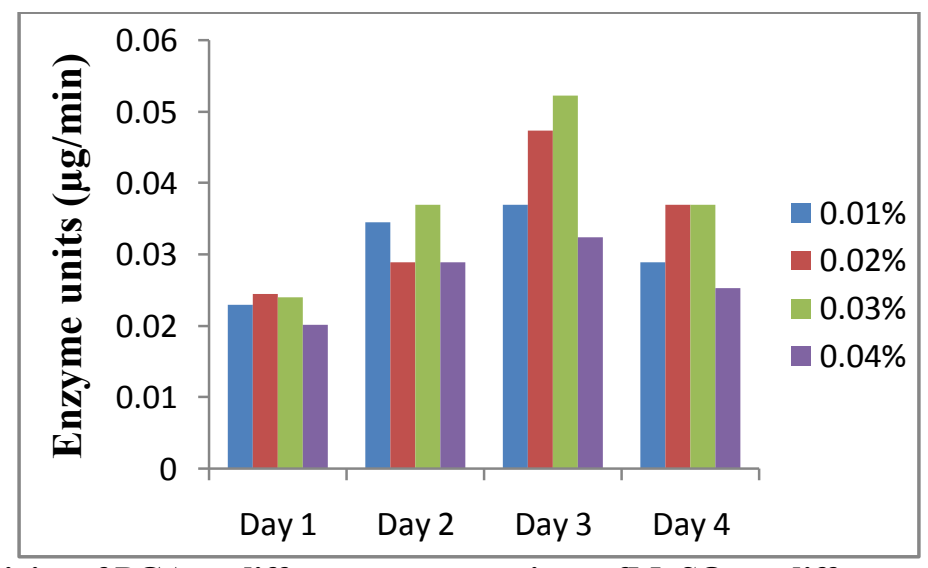

Fig.5. Enzyme activity of PGA at different concentrations of $\mathrm{MgSO}_{4}$ at different days of incubation. 


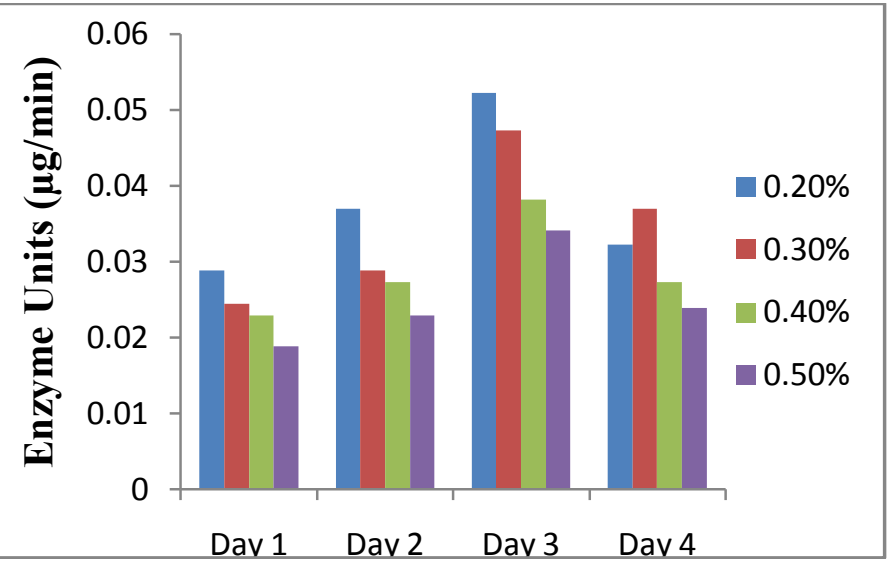

Fig.6. Enzyme activity of PGA at different concentrations of $\mathrm{KH}_{2} \mathrm{PO}_{4}$ on different days of incubation.

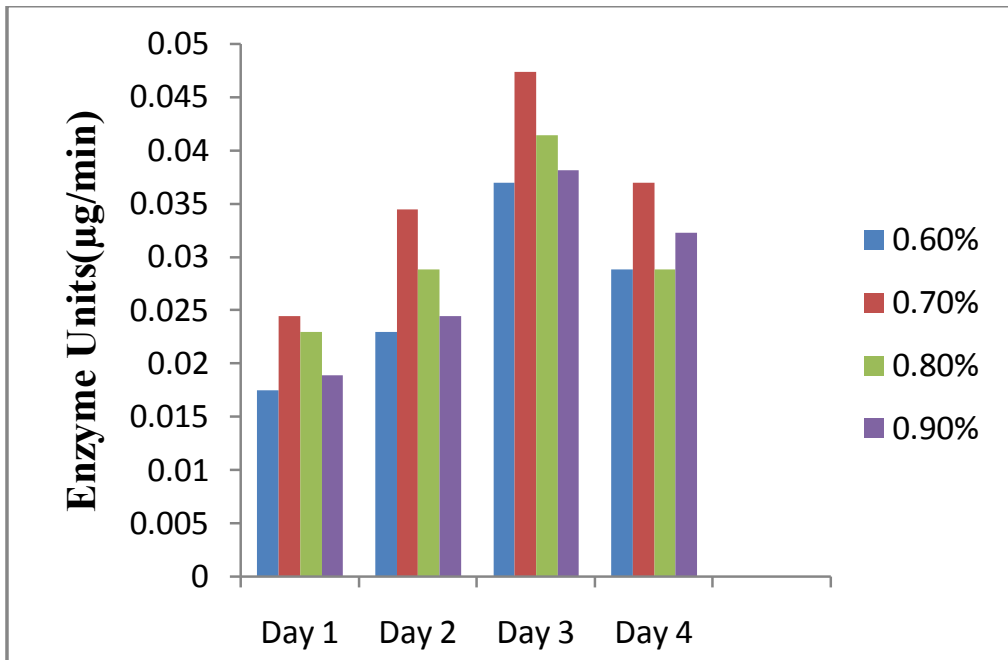

Fig.7.Enzyme units of PGA at different concentrations of $\mathrm{K}_{2} \mathrm{HPO}_{4}$ on different days of incubation.

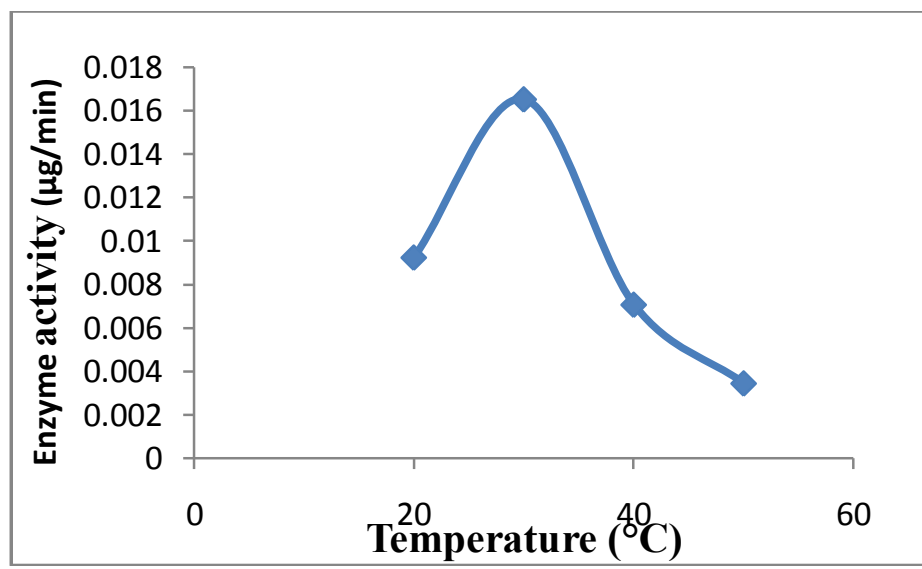

Fig.8. Enzyme units of PGA at different temperatures of incubation. 


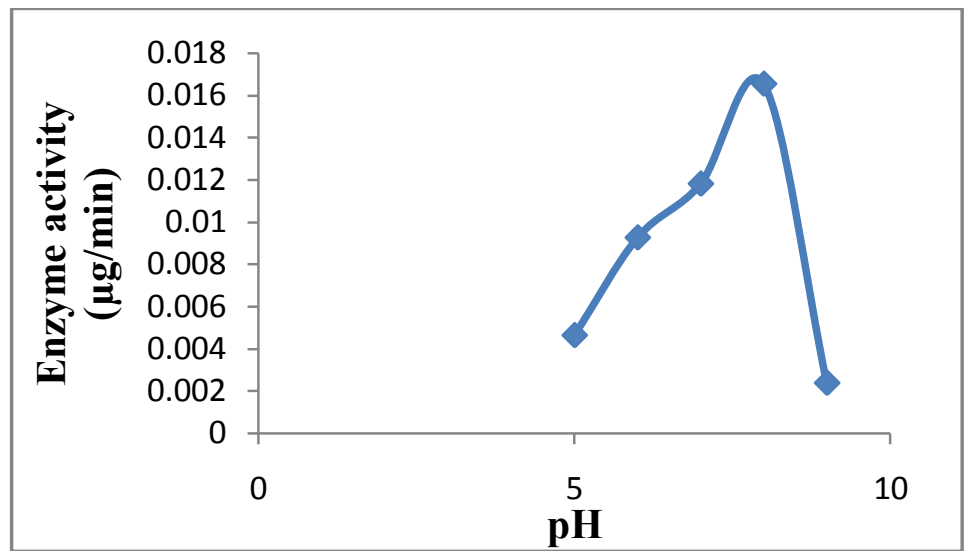

Fig.9. Enzyme units of PGA at different pH incubation.

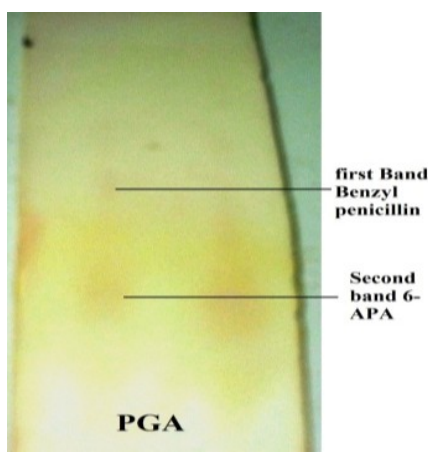

Fig.10. TLC plate with Penicillin G Acylase shows two bands of 6-APA and Benzyl penicillin.
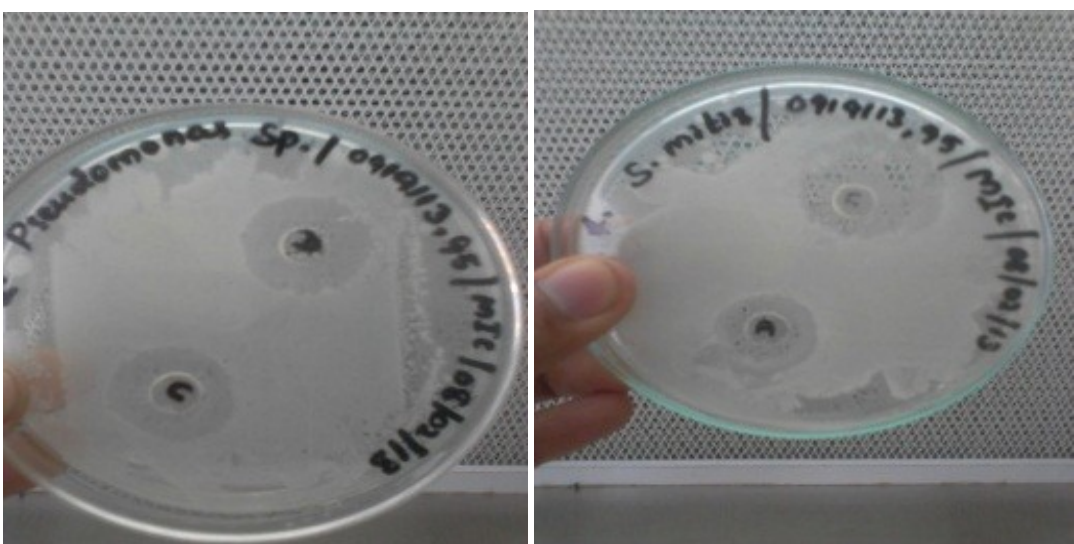

Fig.11. Streptococcus mitis- A - $1.5 \mathrm{~cm}, \mathrm{C}-1.4$ Fig.12.Pseudomonas aeruginosa- A - $1.6 \mathrm{~cm}, \mathrm{~B}-1.5 \mathrm{~cm}$

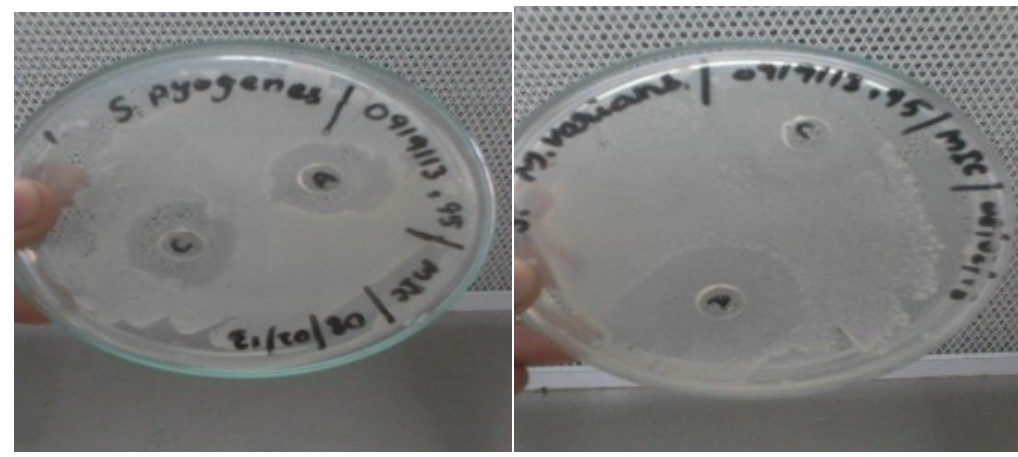

Fig.13.Streptococcus pyogenes- A - $1.5 \mathrm{~cm}, \mathrm{C}-1.5 \mathrm{~cm}$ Fig.14.Micrococcus varians- A - $2.1 \mathrm{~cm}, \mathrm{~B}-2 \mathrm{~cm}$. 


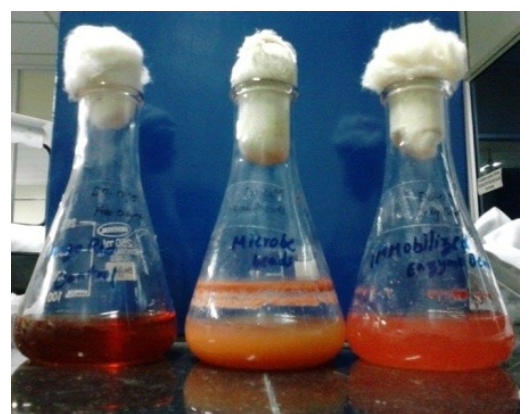

Fig.15.Dye decolorizing activity of immobilized Penicillium chrysogenum and enzyme with control $(0.01 \%)$ congo red dye solution

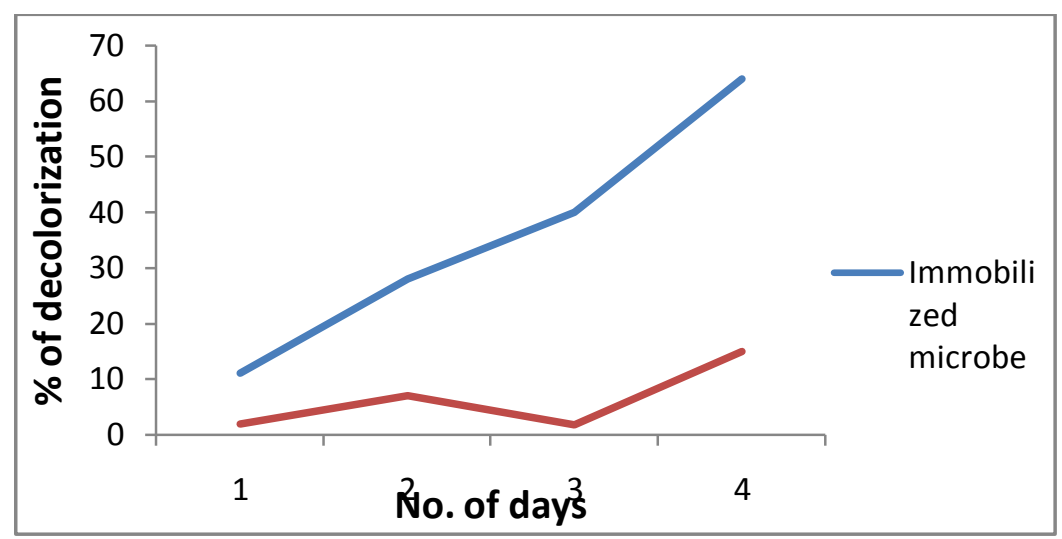

Fig.15. Decolorizing activity of immobilized enzyme and microorganism against congo red

\section{Conclusion}

Penicillin G Acylase producing fungi were isolated and screened from lemon waste, an easily available source. The fungal microorganism was confirmed as Penicillium chrysogenum from colony morphology and microscopic characteristics (LPCB staining). Media was optimized and yield of PGA from optimized media was found to be of higher concentration. The enzyme was largely present on the supernatant at third day; similarly the production of PGA was also higher at optimized carbon source (glucose), $\mathrm{pH}(8)$ and temperature $\left(30^{\circ} \mathrm{C}\right)$.

The enzyme solution obtained after purification from ammonium sulphate precipitation, dialysis and ion-exchange chromatography showed highest yield in Elute $D$ with an enzyme unit of $0.0231 \mu \mathrm{g} / \mathrm{min}$. $R_{\mathrm{f}}$ values of benzyl penicillin (0.7) and 6-APA (0.25) deduced from Thin Layer Chromatography confirmed the presence of PGA in the sample. Purified enzyme solution had good anti-microbial activity, showing a clear zone of inhibition against bacterial pathogens such as Pseudomonas aeruginosa $(1.6 \mathrm{~cm})$, Streptococcus mitis $(1.5 \mathrm{~cm})$, Streptococcus pyogenes $(1.5 \mathrm{~cm})$ and a maximum for Micrococcus varians $(2.1 \mathrm{~cm})$. On testing the dyedecolourizing property with Congo red dye, it was concluded that immobilized Penicillium chrysogenum has more decolourizing activity (upto 64\%) than immobilized PGA enzyme (only 15\%). Thus, the microorganism can be most effectively used for treating the industrial dye effluents.

\section{Acknowledgement}

Wesincerely thank Dr.ManasRanjanBarik and Ms.AnnanyaMohapatraofDNA Labs India, Hyderabadfor kindly providing us all the requirements and assistance for our project work. We extend our sincere thanks toMrs.MalarselviSethupathy,Department of Biotechnology, Government College of Technology, Coimbatore, for supporting us throughout the project work. We honestly thank our parents,Mr.MahendiranMrs.Kalaiselvi, Mr.Duraisamy-Mrs.Vasanthiand our friendsMr.Dileepan, Mr.Vairamuthu, Mr.Matharsahib and Mr.Vigneshfor their moral support. We also thank the Almighty God for giving us the courage and strength for the successful completion of this project.

\section{References}

[1]. W. S. Adriano2, E. H.C. Filho1, J. A. Silva1, R. L. C. Giordano2 and L. R.B. Gonçalves1STABILIZATION OF PENICILLIN G ACYLASE BY IMMOBILIZATION ON GLUTARALDEHYDE-ACTIVATED CHITOSAN. Brazilian Journal of Chemical Engineering Vol. 22, No. 04, pp. 529 - 538, October - December, 2005.

[2]. Vivek Tembhurkar1, Anuradha Patil2, Chetan Chaudhari3, Manjiree Kulkarni3, Sanjay Harke3 Penicillin Acylase Production By Micrococcus luteusandStaphylococcus spp. Isolated from Soda Lake IOSR Journal of Pharmacy Vol. 2(2) pp: 296-301, (2012) 
[3]. Burtscher, H.; Schumacher, G. 1992. "Reconstitution in vivo of penicillin G acylase activity from separately expressed subunits". Eur J Biochem. Pp 77-83.

[4]. MohyEldin, M.S., Schroen, C.G.P.H., Janssen, A.E.M., Mita, D.G. and Tramper, J., Immobilization of Penicillin G Acylase on Chemically Grafted Nylon Particles, Journal of Molecular Catalysis B: Enzymatic, 10, 445 - 451 (2000).

[5]. Guisan, J.M., Bastida, A., Cuesta, C., Fernandez- Lafuente, R. and Rossel, C.M., Immobilization and Stabilization of achimotrypsin by Covalent Attachment to Aldehyde-agarose Gels, Biotechnology and Bioengineering, 38, 1144 -1152 (1991).

[6]. Guan, Y.; Treffry, T. E.; Lilley TH. (1994). E. coli penicillin acylase isolation by selective release, aqueous two-phase portioning and ultrafiltration Bioseparation 6(6) 343-51.

[7]. Fargues, C; Chanel, S Grevillot, G (1996) Location of regulatory gene in penicillin G acylase operon (pacR) of E. coli: An efficient three steps preparative purification of penicillin acylase from E. coli cells.

[8]. Hunt, P. D.; Tolley, S. P.; Ward, R. J.; Hill, C. P.; Dodson, G. G. (1990). Expression, purification and crystallization of penicillin G acylase from E. coli ATCC 11105. Protein Eng. 3: 635-9.

[9]. Dai, Y.; Jing, T. Y.; Wu, J. (1991). Purification and characterization of penicillin acylase from E. coli 108/PPAHDI constructed by DNA recombinant technology. ZhongguoYiyaoGongyeZazhiI. 22: 10-13.

[10]. Kumar Praveen G.N. and Sumangala K. Bhat*Fungal Degradation of Azo dye- Red 3BN and Optimization of Physico-Chemical Parameters. ISCA Journal of Biological Sciences Vol. 1(2), 17-24, June (2012).

[11]. Daneshvar N., Ayazloo M., Khataee A. R. and Pourhassan M., Biological decolorization of dye solution containing Malachite Green by microalgae Cosmariumsp., Bioresource Technology, 98, 1176-1182 (2007).

[12]. Kumar K.V., Ramamurthi V. and Sivanesan S., Dyes and pigments. biosorption of malachite a green cationic dye onto Pithophorasp., a fresh water algae, Dyes andPigments, 69, 74-79 (2006).

[13]. Salar Raj Kumar, Rohilla Suresh Kumar and RohillaJitender Kumar, Decolorization of Reactive Black HFGR by Aspergillussulphureus, Res. J. Recent Sci., 1(1), 55 - 61 (2012).

[14]. Chang J.S., Chou C. and Chen S.Y., Decolorization of azo dyes with immobilized Pseudomonas luteola, ProcessBiochemistry, 36, 757-763 (2001).

[15]. Kheirolomoom, A, Kazemi- Vayasari, Arjmand and Doosty, Optimization of Penicillin G acylase Production, Scientia journal, Vol. 8, No.3, pp 159-65, (2001).

[16]. V. MEEVOOTISOM etal., APPLIED AND ENVIRONMENTAL MICROBIOLOGY,pp. 1227-1229, 1983. 